\title{
Factor VII Measurement
}

National Cancer Institute

\section{Source}

National Cancer Institute. Factor VII Measurement. NCI Thesaurus. Code C81960.

The determination of the amount of factor VII present in a sample. 